\title{
Varieties of Skills Profiles in Latin America: A Reassessment of the Hierarchical Model of Capitalism
}

\author{
Juan A. Bogliaccini ${ }^{1}$ and Aldo Madariaga ${ }^{2 \star}$ \\ ${ }^{1}$ Department of Social and Political Sciences, Universidad Católica del Uruguay, Montevideo, Uruguay and \\ ${ }^{2}$ Centro de Economía y Políticas Sociales (Centre for Economics and Social Policy, CEAS), Universidad \\ Mayor, Chile. \\ ${ }^{\star}$ Corresponding author. Email: aldo.madariaga@umayor.cl.
}

(First published online 29 May 2020)

\begin{abstract}
Research on the politics of skills formation in Latin America is severely underdeveloped. This article offers a novel characterisation of the supply of skills in the region or 'skills supply profiles', taking inspiration from the comparative capitalisms literature. We identify four configurations of skills supply profiles - universalising, dual academic-oriented, dual VET-oriented and exclusionary - and analyse their historical dynamics. By doing this, we challenge general assessments of Latin America's skills formation systems as pertaining to one overarching type. This sets the stage for a deeper understanding of the politics of skills in the region and their connection with different development alternatives.
\end{abstract}

Keywords: skills; Latin America; development; vocational education and training

\section{Introduction}

Education and the acquisition of skills are the cornerstones of economic growth and technological progress. Today, it is widely agreed that Latin America's lack of a skilled workforce is one of the most daunting impediments to achieving higher levels of economic and social development. ${ }^{1}$ Not surprisingly, the region has been portrayed as being caught in a 'low skills, bad jobs trap'. ${ }^{2}$ Yet, while this relation between skills and development is relatively clear and widely shared, there is an important gap in understanding the politics behind successful skills-formation policies.

\footnotetext{
${ }^{1}$ Eric A. Hanushek and Ludger Woessmann, The Knowledge Capital of Nations: Education and the Economics of Growth (Cambridge, MA: MIT Press, 2015); Carmen Pagés, Gaëlle Pierre and Stefano Scarpetta, Job Creation in Latin America and the Caribbean: Recent Trends and Policy Challenges (Washington, DC and Basingstoke: World Bank and Palgrave Macmillan, 2009); Jeffrey Puryear and Tamara Ortega Goodspeed, 'How Can Education Help Latin America Develop?', Journal of Emerging Market Economies, 3: 1 (2011), pp. 111-34.

${ }^{2}$ Ben Ross Schneider and Sebastian Karcher, 'Complementarities and Continuities in the Political Economy of Labour Markets in Latin America', Socio-Economic Review, 8: 4 (2010), p. 633.

(c) Cambridge University Press 2020
} 
A wave of recent contributions in political science has significantly advanced our understanding of the politics behind skills formation. ${ }^{3}$ Many of these take as a starting point the comparative capitalisms literature, reflecting the importance of a theoretical and empirical investigation of the enduring variation in skills formation among countries as a key step to advance the analysis of the political causes behind this variation. ${ }^{4}$ Latin America has been conspicuously absent from these debates, and analysis of skills formation in the region remains scarce. There exist general assessments about the lack of a skilled workforce, the low quality of skills, and the mismatch between skills supply and labour-market demand. ${ }^{5}$ However, beyond a pair of characterisations of the institutions involved in technical and vocational education and training (VET), there is no systematic analysis of the type and level of skills supply. ${ }^{6}$ As Ben Ross Schneider has compellingly argued, in order to advance towards a better understanding of skills formation in Latin America - as well as its relationship to countries' prospects for development - it is crucial to study skills supply through education and training systems. ${ }^{7}$ This article intends to contribute precisely to the understanding of cross-case variation in skills supply in Latin America as a necessary step in order to achieve a better comprehension of the politics behind such variation.

Our analysis takes as a starting point - and contributes to - two strands of literature. Primarily, we aim to contribute to the literature on Latin American capitalisms and their development perspectives. ${ }^{8}$ The most extended interpretation of Latin America's variety of capitalism is that of Schneider and his colleagues. ${ }^{9}$ In

\footnotetext{
${ }^{3}$ See Marius Busemeyer and Christine Trampusch, 'Review Article: Comparative Political Science and the Study of Education', British Journal of Political Science, 41: 2 (2011), pp. 413-43; Thomas Gift and Eric Wibbels, 'Reading, Writing, and the Regrettable Status of Education Research in Comparative Politics', Annual Review of Political Science, 17 (May 2014), pp. 291-312.

${ }^{4}$ Marius Busemeyer, Skills and Inequality: Partisan Politics and the Political Economy of Education Reforms in Western Welfare States (New York: Cambridge University Press, 2015); Cathie Jo Martin, 'Skill Builders and the Evolution of National Vocational Training Systems', in Chris Warhust, Ken Mayhew, David Finegold and John Buchanan (eds.), The Oxford Handbook of Skills and Training (Oxford: Oxford University Press, 2017), pp. 36-53.

${ }^{5}$ See Matías Busso, Marina Bassi, Sergio Urzúa and Jaime Vargas, Disconnected: Skills, Education, and Employment in Latin America (Washington DC: Inter-American Development Bank, 2012); Carolina González-Velosa, David Rosas and Roberto Flores, 'On-the-Job Training in Latin America and the Caribbean: Recent Evidence', in Matteo Grazzi and Carlo Pietrobelli (eds.), Firm Innovation and Productivity in Latin America and the Caribbean (Washington, DC: Inter-American Development Bank, 2016), pp. 137-65; Pagés et al., Job Creation in Latin America.

${ }^{6} J u a n$ José Llisterri, Nicolo Gligo, Oriol Homs and Domenec Ruíz-Devesa, 'Educación técnica y formación profesional en América Latina: El reto de la productividad', Serie Políticas Públicas y Transformación Productiva, № 13 (Caracas: Banco de Desarrollo de América Latina (CAF), 2013); María Paola Sevilla, 'Panorama de la educación técnica profesional en América Latina y el Caribe', Serie Políticas Sociales, Nº. 222 (Santiago de Chile: Comisión Económica para América Latina y el Caribe (CEPAL), 2017).

${ }^{7}$ Ben Ross Schneider, Hierarchical Capitalism in Latin America: Business, Labor, and the Challenges of Equitable Development (New York: Cambridge University Press, 2013).

${ }^{8}$ See Aldo Madariaga, 'Variedades de capitalismo y su contribución al estudio del desarrollo en América Latina', Política y Gobierno, 25: 2 (2018), pp. 441-68; Matthias Ebenau, 'Comparative Capitalisms and Latin American Neodevelopmentalism: A Critical Political Economy View', Capital and Class, 38: 1 (2014), pp. $102-14$.

${ }^{9}$ Schneider, Hierarchical Capitalism; Schneider and Karcher, 'Complementarities and Continuities'; Ben Ross Schneider and David Soskice, 'Inequality in Developed Countries and Latin America: Coordinated, Liberal and Hierarchical Systems', Economy and Society, 38: 1 (2009), pp. 17-52.
} 
a study of the region's labour markets and their relation with skills formation, Schneider and Sebastian Karcher have argued that 'from a comparative perspective what stands out is the relative absence of significant variation, compared both with other regions and other dimensions of change in the political economies of Latin America? ${ }^{10}$ This assessment has led Schneider and colleagues to portray the region as belonging to an overarching variety of capitalism they call 'hierarchical market economies' (HME). Although the analysis of skills-formation systems and their relationship with skills demand and a series of complementary institutions is one of the strongest aspects of these studies, the focus on overarching commonalities conceals the large and meaningful intra-regional differences related to education and skills. Conversely, alternative conceptualisations of the region's capitalist diversity that do consider intra-regional differences do not devote a significant space to analysing skills as part of these varieties. ${ }^{11}$ Due to the central role that skills formation plays in conceptualisations of capitalism's institutional diversity and its consequences in terms of economic and social development, one key contribution of this article is, precisely, to advance the understanding of skills formation as a constituting part of Latin America's varieties of capitalism. In this context, our analysis challenges the dominant idea that the region is characterised by an overall pattern of skills supply, as depicted in the HME model.

Secondly, we draw from - and contribute to - the literature on welfare, social policy and development. There is a long research tradition devoted to understanding the variation in Latin America's social policy regimes, the politics explaining this variation, and their contribution to the incorporation of excluded populations in economic and social development dynamics. ${ }^{12}$ In some of these works, education features as a key component of welfare and social policy. ${ }^{13}$ However, by subsuming the analysis of skills formation under the rubric of human capital, education policy and/or social policy reform, these works obscure the intrinsic dynamic of education as skills formation, and its close relation with productive structures and labour markets. ${ }^{14}$ Studies of

\footnotetext{
${ }^{10}$ Schneider and Karcher, 'Complementarities and Continuities', p. 632.

${ }^{11}$ For example, Ilan Bizberg claims that 'We are not able to include other relevant elements such as the educational and qualification system [...] for lack of space.' Ilan Bizberg, 'Types of Capitalism in Latin America', Revue Interventions économiques, 49 (May 2014), fn. 2. See also Juan A. Bogliaccini, 'Small Latecomers into the Global Market Power Conflict and Institutional Change in Chile and Uruguay', PhD diss., University of North Carolina, Chapel Hill, 2012.

${ }^{12}$ Fernando Filgueira, Welfare and Democracy in Latin America: The Development, Crises, and Aftermath of Universal, Dual, and Exclusionary Social States (Geneva: UNRISD, 2005); Stephan Haggard and Robert Kaufman, Development, Democracy and Welfare States (Princeton, NJ: Princeton University Press, 2008); Evelyne Huber and John Stephens, Democracy and the Left: Social Policy and Inequality in Latin America (Chicago, IL: Chicago University Press, 2012); Juliana Martínez-Franzoni, 'Welfare Regimes in Latin America: Capturing Constellations of Markets, Families, and Policies', Latin American Politics and Society, 50: 2 (2008), pp. 67-100; Jennifer Pribble, Welfare and Party Politics in Latin America (New York: Cambridge University Press, 2013); Alex Segura-Ubiergo, The Political Economy of the Welfare State in Latin America: Globalization, Democracy, and Development (New York: Cambridge University Press, 2007).

${ }^{13}$ Huber and Stephens, 'Democracy and the Left'; Pribble, Welfare and Party Politics; Segura-Ubiergo, The Political Economy of the Welfare State; Haggard and Kaufman, Development, Democracy and Welfare States.

${ }^{14}$ But see Juliana Martínez-Franzoni and Diego Sánchez-Ancochea, 'Can Latin American Production Regimes Complement Universalistic Welfare Regimes? Implications from the Costa Rican Case', Latin American Research Review, 48: 2 (2013), pp. 148-73.
} 
education as skills formation have found an intricate relationship between welfare systems and skills formation systems. ${ }^{15}$ However, as Eric Hanushek and Ludger Woessmann have convincingly argued, the difference between overall education and a concrete focus on cognitive skills is key to understanding the effect of education on development. ${ }^{16}$

In this article, we study education from the lens of skills formation. As opposed to the existing literature on education policy, we put special emphasis on VET at different educational levels, considering skills formation and human capital formation as possible alternative paths of incorporation behind social policy reform efforts. ${ }^{17}$ In order to do so, we provide what is - to the best of our knowledge the first systematic characterisation of the variety of skills portfolios in the region, or what we call 'skills supply profiles', and their underlying configurations.

The literature of the two avenues of research mentioned above has relied greatly on theoretical and empirical classification techniques to show cross-case variation in particular, cluster analysis. ${ }^{18}$ Following this approach, we use quantitative data on skills supply - education enrolment, attainment and cognitive scores - to build clusters of countries in terms of their skills portfolio. The use of cluster analysis allows us to generate groups that are both empirically grounded and theoretically sound. We argue that there exist four configurations of skills profiles in the region: universalising, dual academic-oriented, dual VET-oriented and exclusionary. Although our analysis is cross-sectional and describes a post-structural adjustment scenario, we make use of secondary sources and data for assessing longitudinal trajectories, from the import substitution industrialisation (ISI) period to the present, when describing these profiles.

The article is organised as follows: First, we ground our work on the literature reviewed and highlight the common challenges that Latin American countries face in terms of skills formation and the relation this has to their development prospects. Second, advancing to our main argument, we show that underneath common traits and developmental challenges lie a variety of configurations we call skills supply profiles. We develop this concept and its main characteristics, and

\footnotetext{
${ }^{15}$ Busemeyer, Skills and Inequality; Torben Iversen and John D. Stephens, 'Partisan Politics, the Welfare State, and Three Worlds of Human Capital Formation', Comparative Political Studies, 41: 4-5 (2008), pp. 600-37.

${ }^{16}$ Hanushek and Woessmann, The Knowledge Capital of Nations.

${ }^{17}$ See Segura-Ubiergo, The Political Economy of the Welfare State. Although skills formation usually also covers lifelong learning and in-firm training, data for the region is very scattered, which makes it difficult to systematically study them. Moreover, existing research shows that in-firm training in the region is very scarce outside large internationalised firms. See Juan Eberhard, Gabriel Moraga, Eleonora Nun and Aldo Madariaga, 'The On-the-Job Training Decision in Latin America', IDB Working Paper Series, no. IDB-WP-772 (Washington DC: Inter-American Development Bank, 2017); Schneider, Hierarchical Capitalism.

${ }^{18}$ See, for example, Bruno Amable, The Diversity of Modern Capitalism (New York: Oxford University Press, 2003); Martin R. Schneider and Mihai Paunescu, 'Changing Varieties of Capitalism and Revealed Comparative Advantages from 1990 to 2005: A Test of the Hall and Soskice Claims', Socio-Economic Review, 10: 4 (2012), pp. 731-53; Gøsta Esping-Andersen, The Three Worlds of Welfare Capitalism (Princeton, NJ: Princeton University Press, 1990); Martínez-Franzoni, 'Welfare Regimes in Latin America'; John S. Ahlquist and Christian Breunig, 'Country Clustering in Comparative Political Economy', MPIfG Discussion Paper, no. 09/5 (Cologne: MPIfG, 2009).
} 
conduct our empirical analysis using the cluster analysis technique. Third, we identify and characterise the region's skills profiles. We characterise them with a special focus on six cases: Chile, Brazil, Bolivia, Guatemala, Mexico and Uruguay, representing meaningful dynamics within each. We conclude by emphasising how our results help advance the understanding of the relationship between skills and development in Latin America.

\section{Common Traits of Skills Formation in Latin American Capitalism(s)}

We define 'skills' as the abilities acquired through formal and informal education that provide concrete know-how and allow the performance - and potential improvement - of specific tasks. ${ }^{19}$ For the most part, these abilities are acquired in standardised educational and training contexts, and comprise both specific and broad knowledge. ${ }^{20}$ Skills are valued in different ways in the labour market in relation to their capacity to be used in concrete jobs, and to increase the productivity of labour. By 'skills supply profile', we refer to the overall quantity, quality and type of skills that an economy offers, and that are embodied in the workforce's diverse characteristics and capacity to participate in processes of economic production and transformation, broadly conceived. In the next section we define what we mean by quantity, quality and type of skills.

There is a direct relation between skills profiles and development. ${ }^{21}$ On the one hand, a high supply of skills promotes industrial upgrading from lower to higher value-added sectors and the incorporation of more complex technologies and production processes. As the comparative capitalism literature has highlighted, the types of skills provided - whether general-academic or specific-technical - allow for different economic specialisation patterns. ${ }^{22}$ On the other hand, the growth in the demand for skills, due to companies incorporating more capital and/or using technologies and processes that are more complex, induces countries and workers to respond by increasing their supply.

The value of skills is socially constructed, and their supply and demand are intricately linked to political and historical processes. ${ }^{23}$ Development scholars have argued that concrete policy interventions in the two sides are needed to produce successful development experiences. ${ }^{24}$ While upgrading skills portfolios through

\footnotetext{
${ }^{19}$ The concept of 'skills' is a contested one across disciplinary boundaries and has acquired different meanings over time and space. For a discussion, see Jonathan Payne, 'The Changing Meaning of Skill: Still Contested, Still Important', in Chris Warhust et al. (eds.), The Oxford Handbook of Skills and Training, pp. 54-71.

${ }^{20}$ In this article, we focus on the formal dimensions of skills acquisition. However, this should not obscure the fact that much of this acquisition occurs through prolonged experience and routinised problem-solving on the job. See Sanjaya Lall, 'Skills, Competitiveness and Policy in Developing Countries', Greek Economic Review, 19: 2 (1999), pp. 81-104.

${ }^{21}$ Hanushek and Woessmann, The Knowledge Capital of Nations; Claudia Goldin and Lawrence F. Katz, The Race between Education and Technology (Cambridge, MA: Belknap Press, 2008); Lall, 'Skills, Competitiveness and Policy'.

${ }^{22}$ Busemeyer, Skills and Inequality; Iversen and Stephens, 'Partisan Politics, the Welfare State'.

${ }^{23}$ Payne, 'The Changing Meaning of Skill', pp. 56-7.

${ }^{24}$ Lall, 'Skills, Competitiveness and Policy'; Sanjaya Lall, 'The Technological Structure and Performance of Developing Country Manufactured Exports, 1985-98', Oxford Development Studies, 28 : 3 (2000), pp. 337-69.
} 
expanding education and training is a pre-condition for producing higher valueadded goods, productive development policies are key to incentivising investment in economic sectors with higher technological content and skills requirements. Historically, Latin American economies have lacked both.

\section{Low-Productivity Economies and Early De-industrialisation}

In Latin America, the analysis of economic structure as a hindrance to development, in the attempt to understand the characteristics of the backwardness of the region's capitalisms, has a long pedigree. There is a striking historical continuity in this assessment: Latin America is characterised by a pattern of specialisation in low-productivity activities and the export of raw materials and products with little technological sophistication and that require few skills to manufacture or extract. ${ }^{25}$ Even the countries that have advanced more in producing and exporting higher technology-content products are placed in the early stages of global value chains, where productive processes tend to be simple assembly ones, requiring minimal skills sets. ${ }^{26}$ Moreover, the region is said to be part of an 'early de-industrialization pattern': a premature expansion of the service sector in detriment to higher skills-demanding manufacturing sectors. ${ }^{27}$ In the post-structural adjustment period, this expansion of services did not lead to high-productivity service sectors like in advanced countries, but the opposite, increasing the segments of low-productivity services and informal jobs that require minimum skills.

Based on Economic Commission for Latin America and the Caribbean (ECLAC) calculations, Figure 1 shows changes in the share of employment within two categories of different economic sectors, aggregated according to their productivity levels: low productivity (agriculture, commerce and services) and high productivity (financial activity, electricity and mining). ${ }^{28}$ If there were significant changes, we would expect to see the upper-left area and the lower-right area populated by low and high productivity, respectively. The data shows that this is far from the truth.

With the exception of Costa Rica and Mexico, employment in high-productivity sectors has increased by only a few percentage points and remains at a regional average of less than 8 per cent. Conversely, employment in low-productivity sectors has remained relatively static, at a high 67 per cent, on average. The contribution of each sector to GDP is almost exactly the opposite: 67 per cent is produced by the high-productivity sector, while only around 10 per cent is generated by the employment-intensive low-productivity sector. ${ }^{29}$ For comparison purposes, around 2010 in the Republic of Korea, only 33 per cent of employment was in low-

\footnotetext{
${ }^{25}$ See, for example, Eva A. Paus, 'Productivity Growth in Latin America: The Limits of Neoliberal Reforms', World Development, 32: 3 (2004), pp. 427-45; ECLAC, Structural Change for Equality: An Integrated Approach to Development (Santiago: ECLAC, 2012).

${ }^{26}$ Paus, 'Productivity Growth in Latin America'.

${ }^{27}$ José G. Palma, 'Industrialization, "Premature" Deindustrialization and the Dutch Disease', Revista NECAT, 3: 5 (2014), pp. 7-23.

${ }^{28}$ The sectors are grouped by ECLAC according to their average labour productivity. Medium productivity includes construction, manufacturing and transportation.

${ }^{29}$ ECLAC, Structural Change, pp. 209-10.
} 

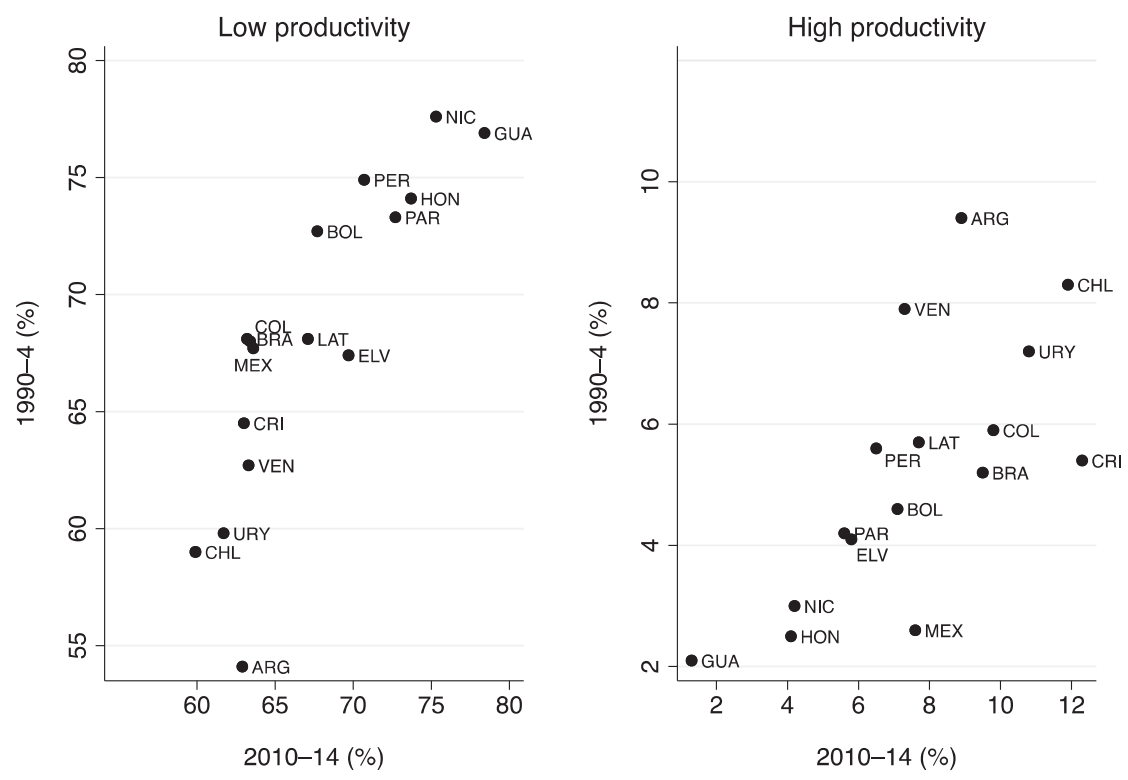

Figure 1. Employment in Low- and High-Productivity Sectors. Latin America, 1990-2014 Source: Authors' elaboration based on data from ECLAC's CEPALSTAT database.

productivity sectors, while high-productivity sectors accounted for about 28 per cent of employment. ${ }^{30}$

This characteristic of Latin America's economies has been called 'structural heterogeneity'; that is, the 'coexistence in a single economy of production sectors that would be characteristic of economies at different stages of development, with lowproductivity segments figuring heavily. ${ }^{31}$ This overarching situation reduces demand for skills as well as incentives to invest in skills, as it segments the labour market into two broad strata: one large segment of low-skilled workers, with high labour rotation and mobility across economic sectors, who enter and exit formality following economic cycles; and one small segment of elite, higher-skilled workers, with higher wages and higher job security. ${ }^{32}$

\section{Low-Skilled Workforce and Underdeveloped Education Systems}

Latin American social policy was developed in tandem with the consolidation of nation-states and acquired a new impetus under ISI. ${ }^{33}$ Scholars argue that the character of industrialisation made these systems similar to those of Southern European corporatist welfare states: biased towards the urban and male workforce and heavily weighted towards social security benefits, particularly pension schemes, in social

\footnotetext{
${ }^{30}$ Ibid., p. 211.

${ }^{31}$ Ibid., p. 198.

${ }^{32}$ Schneider, Hierarchical Capitalism, pp. 91-2; Schneider and Karcher, 'Complementarities and Continuities'.

${ }^{33}$ Haggard and Kaufman, Development, Democracy and Welfare States; Filgueira, Welfare and Democracy in Latin America.
} 
expenditure. ${ }^{34}$ In the case of education, the focus was mostly on universalising primary education, while academic programmes were the most common in secondary and post-secondary education. With time, countries built vocational training institutions (VTIs) similar to those existing in continental Europe. ${ }^{35}$ However, with the exception of Brazil, they did so relatively late in their industrialisation process (in the 1960s and 1970s). Moreover, they had already begun to roll them out as a response to increasing unemployment from ailing manufacturing industries and the rise of the Washington Consensus in the 1980s. This period brought a focus on targeted training policies as a substitute for social policy for the unemployed and 'unemployable', rather than as mechanisms of skills formation to meet industrial demand or technological upgrading. ${ }^{36}$ Therefore, as a general rule, VTIs did not play an important role in skills formation, and active labour-market policies were practically inexistent before the 1980s.

During the 1980s, it became clear that both ISI and the associated social policy regimes were exhausted. Although they had led the first phase of social incorporation in the region, they had created a situation of strong segmentation between protected formal workers and a large mass of informal and poor workers with no access to education or social security. In addition, the heavy weight of contributory schemes on public expenditure made state efforts, in reality, regressive. ${ }^{37}$

The emphasis on social security and the neglect of education showed a stark contrast to the success of the East Asian economic miracles and their human capital-oriented social policy and industrialisation processes. ${ }^{38}$ While Latin American countries had better education and development indicators than East Asian countries in the 1960s, by the 1980s the region was clearly lagging behind the East Asian newly industrialised countries (NICs). This is largely explained by the emphasis put on education policy and the type of education. In the 1980s, while expenditure on education was similar in both regions, East Asian NICs spent more and more equally on the early stages (primary and secondary), while dropout rates in Latin America more than doubled those of East Asia. ${ }^{39}$ More significantly, East Asian NICs put special emphasis on learning and improving skills, rather than just increasing school attendance and attainment. ${ }^{40}$ Therefore, after the 1990s a new impetus was given to human capital and in particular skills formation in Latin America as a strategy for social incorporation. ${ }^{41}$

\footnotetext{
${ }^{34}$ See ibid.; Armando Barrientos, 'Labour markets and the (Hyphenated) Welfare Regime in Latin America', Economy and Society, 38: 1 (2009), pp. 87-108.

${ }^{35}$ ECLAC/ILO, The Employment Situation in Latin America and the Caribbean: Challenges and Innovations in Labour Training (Santiago: ECLAC/ ILO, 2013).

${ }^{36}$ See Lawrence Wolff and Claudio de Moura Castro, 'Education and Training: The Task Ahead', in Pedro Pablo Kuczynski and John Williamson (eds.), After the Washington Consensus: Restarting Growth and Reform in Latin America (Washington, DC: Institute for International Economics, 2003), pp. 181-211.

${ }^{37}$ For a discussion, see Haggard and Kaufman, Development, Democracy and Welfare States.

${ }^{38}$ Ibid.; Hanushek and Woessmann, The Knowledge Capital of Nations.

${ }^{39}$ Haggard and Kaufman, Development, Democracy and Welfare States, pp. 35-8.

${ }^{40}$ Hanushek and Woessmann, The Knowledge Capital of Nations.

${ }^{41}$ Segura-Ubiergo, The Political Economy of the Welfare State; Wolff and Moura Castro, 'Education and Training'.
} 
In spite of this renewed attention, different analyses agree that Latin America still has significantly lower skills levels compared to developed countries. ${ }^{42}$ While the region has been able to close gaps in primary education, the difference widens to 20 percentage points in secondary, and more than 30 in tertiary education, when compared to the Organisation for Economic Cooperation and Development (OECD) ${ }^{43}$ The region has advanced more rapidly in increasing the share of students who attend tertiary education - from 22 to 44 per cent between 1999 and 2014 - compared to those who attend secondary education, the latter advancing only ten percentage points in the same period. Latin America is also conspicuously behind in terms of the acquisition of cognitive skills. On the 40 occasions in which Latin American countries participated in international achievement tests from 1964 to 2003 , the average rank was 31.8 among an average of 34.5 participants. ${ }^{44}$ Finally, a commonality of Latin American countries is the high segmentation of the different education levels in terms of their quality and effective provision of skills for the job market. ${ }^{45}$ In this respect, education is not unlike other domains of social policy in Latin America, characterised by a 'strong stratification of benefits, access conditions and ranks of protection' ${ }^{46}$ In other words, Latin America suffers from chronic problems in the quantity and quality of education, which severely impair its ability to engage in higher technology and productive economic processes.

\section{Varieties of Skills Profiles in Latin America}

As we have seen, skills supply in Latin America shows important commonalities, distinguishing it from other regions. However, these commonalities conceal significant intra-regional differences. Hanushek and Woessmann, for example, consider the Latin American intra-regional variation in cognitive scores to be 'huge' in comparative terms. ${ }^{47}$ Meanwhile, Schneider and Karcher concede that beneath the overall similarities, there are important variations between poorer and more developed countries. ${ }^{48}$ As several authors have acknowledged, educational coverage and attainment, economic structures and other institutions, in many ways, put South American countries closer to the Mediterranean and/or liberal varieties of capitalism in the advanced world, than those of less advanced Central American countries. ${ }^{49}$ We propose that such intra-regional differences are meaningful and

\footnotetext{
${ }^{42}$ Pagés et al., Job Creation in Latin America; Schneider, Hierarchical Capitalism.

${ }^{43}$ Data from UNESCO's UIS database.

${ }^{44}$ Hanushek and Woessmann, The Knowledge Capital of Nations, p. 117.

${ }^{45}$ See Busso et al., Disconnected. For an analysis of Chile, the region's best performer according to international standards, see Alejandra Mizala and Florencia Torche, 'Bringing the Schools Back In: the Stratification of Educational Achievement in the Chilean Voucher System', International Journal of Educational Development, 32: 1 (2012), pp. 132-44.

${ }^{46}$ Filgueira, Welfare and Democracy in Latin America, p. 14.

${ }^{47}$ Hanushek and Woessmann, The Knowledge Capital of Nations, p. 119

${ }^{48}$ Schneider and Karcher, 'Complementarities and Continuities', p. 633.

${ }^{49}$ Juan A. Bogliaccini and Fernando Filgueira, 'Capitalismo en el Cono Sur de América Latina luego del final del Consenso de Washington: ¿notas sin partitura?', Revista del CLAD Reforma y Democracia, 51 (Oct. 2011), pp. 45-82; Andrew Schrank, 'Understanding Latin American Political Economy: Varieties of Capitalism or Fiscal Sociology?', Economy and Society, 38: 1 (2009), pp. 53-61.
} 
challenge the idea that there is only one configuration of skills for the entire region, as the HME model claims.

The literature concerned with the varieties of skills formation in advanced countries focuses on institutional variables such as the prominence of education provision between state or private institutions; the degree of involvement of the state, business chambers and trade unions in defining training policies; or whether training takes place on the job or in school. ${ }^{50}$ Now, several authors have raised their concerns about directly translating this literature towards a Latin American context. ${ }^{51}$ The greatest concern lies in the application of institutional categories to political economies with significant inter- and intra-national differences in state capacity, and the associated variance in institutional strength and enforcement. ${ }^{52}$ Thus, unlike the literature dealing with advanced countries and centred on institutional differences, we use outcome variables to analyse differences in Latin America. This is consistent with our definition of skills supply profiles and with our emphasis on the relation between the varieties of skills formation and development.

The proposed concept of skills supply profiles is based on two secondary-level dimensions or attributes: the stock and flow of skills supply. The stock of skills reflects the skills already available in the workforce and represents the historical efforts of governments at social incorporation through skills formation. The flow of skills reflects the rate at which skilled individuals join the workforce from the education system and represents recent government efforts at using skills formation as incorporation. ${ }^{53}$ The flow of skills has, in turn, three components: quantity, quality and type of skills being produced in the formal education system.

We argue that both types of measures are important in understanding skills supply because countries not only differ in the overall skill level of their workforce (stock), but also in how these portfolios are changing as education systems improve their coverage and feed the labour market with more skilled workers (flow). Moreover, while it is true that cognitive scores are key indicators for skills acquisition, we argue that the differences in enrolment and attainment within the Latin American region also warrant their inclusion for distinguishing different configurations of skills portfolios. This point was already raised by Fernando Filgueira in his classification of welfare regimes in the region, when he acknowledged the importance of the 'coverage' dimension of social policy as a basic classification criterion for Latin America, but that is not relevant for classifying advanced welfare states where coverage is universal. ${ }^{54}$ In his words, 'when the analyst faces population coverage that vary $[$ sic] in a rank from $20 \%$ to $90 \%$ of the population, she should

\footnotetext{
${ }^{50}$ See, for example, Busemeyer, Skills and Inequality; Iversen and Stephens, 'Partisan Politics, the Welfare State'; Marius Busemeyer, 'Asset Specificity, Institutional Complementarities and the Variety of Skill Regimes in Coordinated Market Economies', Socio-Economic Review, 7: 3 (2009), pp. 375-406.

${ }^{51}$ See, especially, Schrank, 'Understanding Latin American Political Economy'.

${ }^{52}$ See Steven Levitsky and María Victoria Murillo, 'Building Institutions on Weak Foundations', Journal of Democracy, 24: 2 (2013), pp. 93-107; 'Variation in Institutional Strength', Annual Review of Political Science, 12: 1 (2009), pp. 115-33; Marcus J. Kurtz, Latin American State Building in Comparative Perspective: Social Foundations of Institutional Order (New York: Cambridge University Press, 2013); Hillel D. Soifer, State Building in Latin America (New York: Cambridge University Press, 2015).

${ }^{53} \mathrm{This}$ is, of course, an approximate measure and it should be complemented with data on dropout.

${ }^{54}$ Filgueira, Welfare and Democracy in Latin America, pp. 11-12.
} 
seriously look into this point, incorporate it as a discriminate criteria and try to explain it ${ }^{55}$ In fact, in the advanced world, coverage and quality vary little among countries and, therefore, the type of skills available in different skills profiles becomes the most important indicator. ${ }^{56}$ This reinforces the need to focus on different outcome variables when analysing differences in the Latin American region.

One significant challenge for the analysis of the variety of skills profiles in Latin America is the availability and quality of data. Official publications offer different data for the same country; data is available only for recent dates, making historical analyses more difficult; and the complexities of educational systems make data hard to compare. In order to solve this, we make use of the most reliable data in addition to different measures of educational attainment, enrolment and quality of education that reflect both skills stocks and flows. The stock of skills is measured by two slowmoving indicators that allow a precise estimation of the percentage of young potential labour-force participants with minimum general skills: the percentage of the economically active population (aged 15 or above) with only zero to five years of education (that is, approximately, primary education) and the percentage of the population aged between 20 and 24 that has completed secondary education. ${ }^{57}$ Being that Latin America is a poorly skilled region, these indicators do discriminate countries by the stock of skills available in their workforce, affecting the laggard Central American countries to a greater extent than the more advanced South American countries.

The quantity component is represented by a measure of net enrolment in secondary education and a measure of gross enrolment in tertiary education. An indicator of cognitive skills, based on data from UNESCO's Laboratorio Latinoamericano de Evaluación de la Calidad de la Educación (Latin American Laboratory for the Assessment of the Quality of Education, LLECE), measures the quality dimension. ${ }^{58}$ Finally, two indicators measure types of skills. We include a measure of enrolment in secondary VET as a percentage of all students enrolled in upper-secondary education, and a measure of enrolment in tertiary VET - corresponding to International Standard Classification of Education (ISCED) level five programmes - as a percentage of all students enrolled in tertiary education. ${ }^{59}$

\footnotetext{
${ }^{55}$ Ibid., p. 12.

${ }^{56}$ See Iversen and Stephens, 'Partisan Politics, the Welfare State'.

${ }^{57}$ These two variables come from ECLAC's CEPALSTAT database.

${ }^{58}$ LLECE's regional studies evaluate third- and sixth-grade students' competencies in mathematics, reading, writing and natural sciences in a comparative perspective, taking national curricula to set common learning standards in the region. The third edition (2013) involved 15 countries and one sub-national unit. See UNESCO, Comparación de resultados del segundo y tercer estudio regional comparativo y explicativo: SERCE Y TERCE 2006-2013 (Santiago de Chile: UNESCO, 2014). The scores are taken from the average provided by Hanushek and Woessmann, The Knowledge Capital of Nations. We have discarded the use of 'quality' data coming from the PISA programme because it is available for only eight countries in the region. Due to the nature of the cluster analysis and its results based on agglomeration of similar cases, this drop in the number of cases affects the results of the classification exercise. Nevertheless, a comparison between the two measures (LLECE and PISA) shows very similar results. Taking mathematics and reading averages for their latest edition, the ranking of countries is almost equal, except for Colombia and Peru (two countries that we categorise as belonging to the same cluster) swapping the sixth and seventh place.

${ }^{59}$ Data on upper-secondary VET comes from Sevilla, 'Panorama de la educación técnica'; data on postsecondary VET comes from UNESCO's UIS database.
} 
We ran a hierarchical cluster analysis to distinguish different skills supply profiles. ${ }^{60}$ Cluster analysis determines classifications of units (in this case, countries) on the basis of the combination of a predetermined selection criterion (in this case, stocks and flows of skills supply) in an attempt to minimise the difference between units in a group and maximise the differences between groups. Each country in a cluster, therefore, is similar to the others in that cluster and different from countries in the other clusters. ${ }^{61}$ In this way, the clusters represent different types of skills profiles. As hierarchical cluster analysis locates the closest two countries and combines them to form pairs, subsequently joining them together, clusters emerge from the data, facilitating the appearance of taxonomies of skills profiles.

Cluster analysis has been widely applied in the comparative capitalisms literature to replace purely theoretical exercises in the identification of meaningful variations among countries. ${ }^{62}$ Using the clustering technique allows us to analyse groups of variables to overcome the problem of relying on just a few indicators which are based on data of varying quality. Moreover, we use a number of available tests to check the robustness of the selected clustering solution. ${ }^{63}$ Finally, privileging parsimony, we attempt to fit the model by excluding as much redundant information as possible, while not jeopardising its robustness.

The hierarchical type of cluster analysis we use offers an exploratory rather than a confirmatory analysis of the data and, therefore, needs to be complemented with theoretical assessments of the clusters. ${ }^{64}$ In other words, the choice of clusters is not justified solely on statistical grounds, but also on substantive grounds. Finally, to overcome the problems of having only a 'snapshot' cluster solution, in the next section we show how our clusters have moved historically - in this case, between ISI and the open-market economic model. ${ }^{65}$

The results of the cluster analysis are displayed graphically using a dendrogram to facilitate the view of the process by which countries cluster (see Figure 2). Table 1 offers a summary of the variables included in the analysis and detailed above. ${ }^{66}$

\footnotetext{
${ }^{60}$ We use the 'agglomerative hierarchical clustering' method as we conceive groups to be potentially nested, therefore opening the possibility for the existence of sub-clusters. We use a prototype-based approach in which clusters are represented by centroids, using Ward's agglomeration methods in order to minimise the sum of the squared distances of points from their cluster centroids. We have also defined a matrix of Euclidean distances.

${ }^{61}$ See Laurence G. Grimm and Paul R. Yarnold, Reading and Understanding More Multivariate Statistics (Washington, DC: American Psychological Association, 2000); Duncan Cramer, Advanced Quantitative Data Analysis (Maidenhead: McGraw-Hill, 2003).

${ }^{62}$ See Amable, The Diversity of Modern Capitalism; Schneider and Paunescu, 'Changing Varieties of Capitalism'. For a discussion of the technique in comparative political economy, see Ahlquist and Breunig, 'Country Clustering'.

${ }^{63}$ See online Appendix, available at doi.org/10.1017/S0022216X20000322 under the 'Supplementary materials' tab.

${ }^{64}$ Ahlquist and Breunig, 'Country Clustering', p. 11.

${ }^{65}$ For a similar exercise, see Schneider and Paunescu, 'Changing Varieties of Capitalism'.

${ }^{66} \mathrm{We}$ have included Bolivia, Guatemala and Peru in the table. These countries did not enter the cluster analysis for lack of data in the Sevilla indicators for upper-secondary VET, but they can be clearly assigned to one of the clusters, given the data they have for the rest of variables. For other Latin American countries, data is missing in at least two of the variables and, therefore, we decided to leave them out of the analysis.
} 


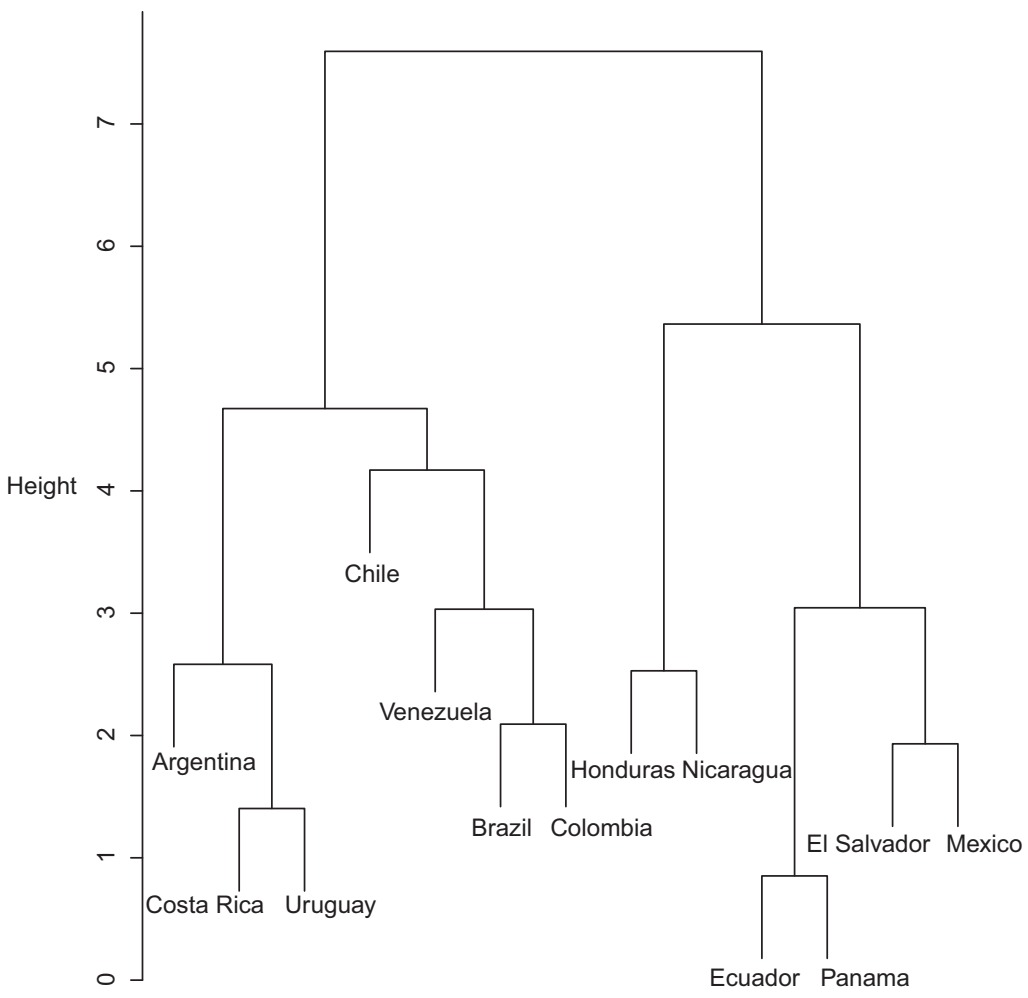

Figure 2. Varieties of Skills Profiles Dendrogram

Notes: Enrolment and attainment data are averages for 2010-12. We assigned the data on cognitive skills for Nicaragua based on UNESCO, Comparación de resultados (TERCE). Ward algorithm used for clustering observations (see footnote 60).

Source: Authors' elaboration based on data from UNESCO's UIS database; ECLAC'S CEPALSTAT database; and Sevilla, 'Panorama de la educación técnica'.

Based on the cluster analysis, we propose that there are two predominant cleavages related to the level and type of skills that account for the different groupings. ${ }^{67} \mathrm{~A}$ first cleavage is the degree to which countries have succeeded in universalising the attainment of 12 years of education, which reflects greater institutional capacity over previous decades. Countries may stagnate, but rarely regress after achieving a certain level. ${ }^{68}$ Here, we identify countries as universalising, dual or exclusionary. These labels are explained below, together with the characterisation of each.

In contrast to the literature on welfare development, when focusing on skills supply we see a significant movement between groups towards the universalising

\footnotetext{
${ }^{67}$ Given a scenario of incomplete incorporation into education, our quality measure does not generate a separate cleavage from the previous two, but reinforces them. In any case, since cognitive scores only consider the portion of the population that is effectively attending school at a corresponding age, quality measures need to be taken with caution precisely because of the important differences the region presents in coverage and attainment.

${ }^{68}$ See Kurtz, Latin American State Building; Soifer, State Building in Latin America.
} 
Table 1. Skills Supply Profiles in Latin America

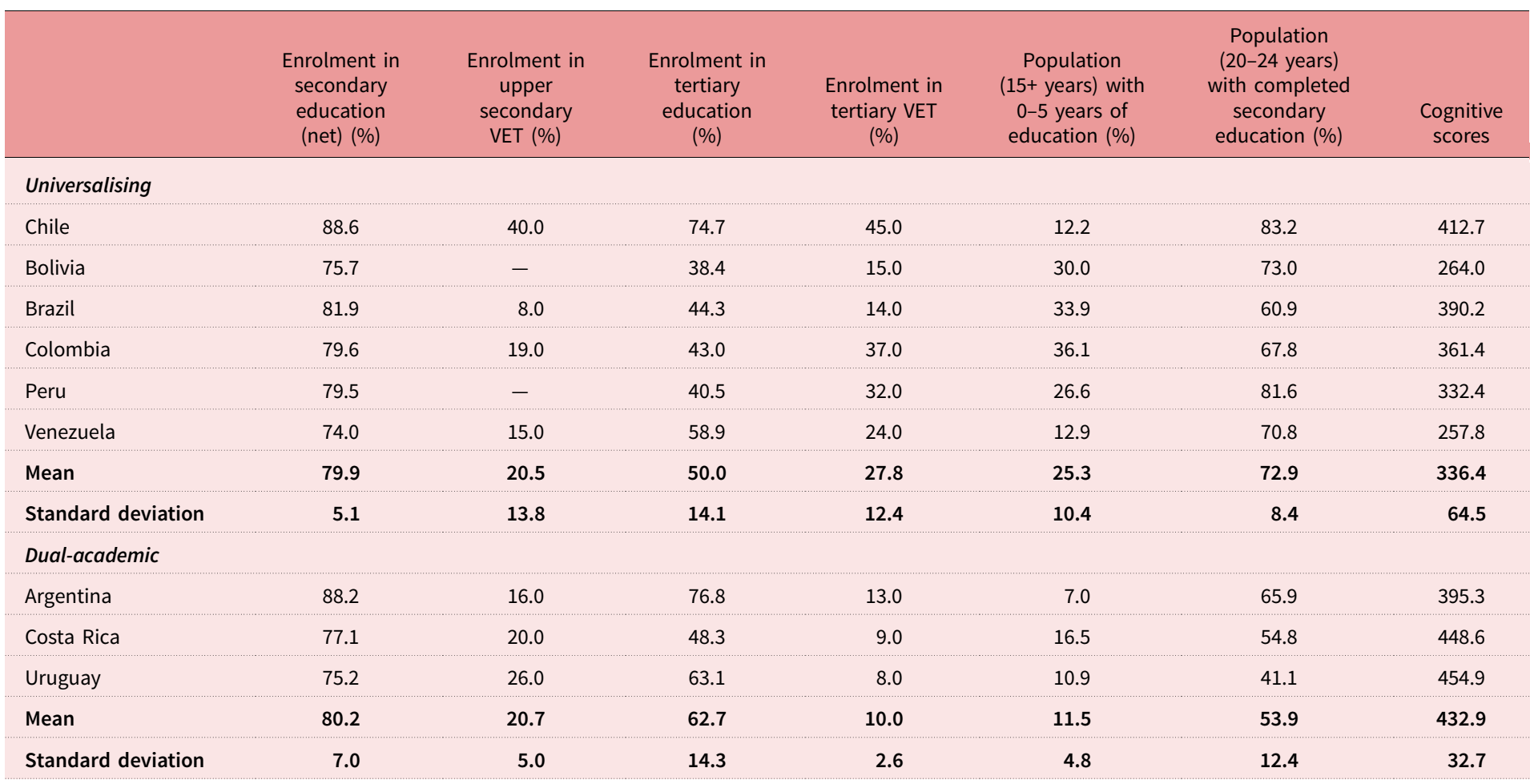


Table 1. (Continued.)

\begin{tabular}{|c|c|c|c|c|c|c|c|}
\hline & $\begin{array}{l}\text { Enrolment in } \\
\text { secondary } \\
\text { education } \\
\text { (net) (\%) }\end{array}$ & $\begin{array}{l}\text { Enrolment in } \\
\text { upper } \\
\text { secondary } \\
\text { VET (\%) }\end{array}$ & $\begin{array}{l}\text { Enrolment in } \\
\text { tertiary } \\
\text { education } \\
(\%)\end{array}$ & $\begin{array}{c}\text { Enrolment in } \\
\text { tertiary VET } \\
(\%)\end{array}$ & $\begin{array}{c}\text { Population } \\
\text { (15+ years) with } \\
0-5 \text { years of } \\
\text { education }(\%)\end{array}$ & $\begin{array}{c}\text { Population } \\
\text { (20-24 years) } \\
\text { with completed } \\
\text { secondary } \\
\text { education (\%) }\end{array}$ & $\begin{array}{c}\text { Cognitive } \\
\text { scores }\end{array}$ \\
\hline \multicolumn{8}{|l|}{ Dual-VET } \\
\hline Ecuador & 82.5 & 48.0 & 39.9 & 12.0 & 18.9 & 63.8 & 285.2 \\
\hline Panama & 77.8 & 50.0 & 43.6 & 5.9 & 14.0 & 59.4 & 298.5 \\
\hline Mean & 74.3 & 47.0 & 34.6 & 13.5 & 22.6 & 54.6 & 319.8 \\
\hline Standard deviation & 7.1 & 6.2 & 8.5 & 7.1 & 10.0 & 8.6 & 37.9 \\
\hline \multicolumn{8}{|l|}{ Exclusionary } \\
\hline Mean & 47.9 & 25.5 & 18.9 & 6.0 & 44.9 & 37.2 & 258.6 \\
\hline Standard deviation & 1.4 & 29.0 & 1.5 & 2.6 & 9.1 & 5.0 & 23.3 \\
\hline
\end{tabular}

Source: Authors' elaboration based on data from UNESCO's UIS database; ECLAC's CEPALSTAT database; and Sevilla, 'Panorama de la educación técnica'. 
skills profile, particularly from countries in the laggard group of exclusionary or dual welfare states - Colombia, Brazil and Venezuela (plus Bolivia and Peru). This is an important finding in itself, as it suggests that a number of countries have been able to break the path dependency of low state capacity and jump onto the bandwagon of incorporation through skills formation. Although medium to low state capacity levels in these countries may put a question mark on the sustainability of the observed changes, reform coalitions in these countries have undoubtedly advanced in the universalisation of skills profiles by drawing on specific policy legacies and bringing in support from new constituencies, thus increasing resources and expanding access. ${ }^{69}$ A second important finding is that many of the countries identified as universal welfare states, namely Argentina, Uruguay and Costa Rica, fall behind when considering their skills profiles. These countries together with Chile - were the pioneers in establishing public education systems and universalising primary education. However, at a time when all countries in the region have managed to universalise enrolment in primary education, and the challenges have moved to universalising a minimum of 12 years of education (secondary education), these countries have remained stuck in levels that are more reminiscent of dual systems, which combine stratified access and lack of universalisation. ${ }^{70}$ Contrary to the situation in the previous group, it seems that existing policy legacies and organised actors in these countries have served as veto players for further institutional reforms, even in the context of high state capacity and institutional strength. ${ }^{71}$ Table 2 shows this transfer of countries between groups when analysed from the point of view of social policy or skills-formation incorporation strategies.

The second cleavage is the degree to which a VET system has developed alongside general education, and the role it fulfils in skills supply. In relation to the prevalence of VET versus academic programmes, this cleavage distinguishes between profiles that have a greater reliance and orientation towards incorporating VET alternatives, and those that have a lower prevalence of VET and are therefore more oriented to academic programmes. In terms of the role of VET, it distinguishes between relying on VET as a way to provide an alternative education for poor populations (i.e. the Washington Consensus view) and skills formation proper, that is, to meet the skills demand of industry and to push for technological upgrade.

Based on this discussion, we propose a solution of four clusters representing four skills supply profiles: universalising, dual academic-oriented, dual VET-oriented and exclusionary. We treat these clusters as a typological classification rather than simply a continuum between high and low, which gives precedence to the understanding of skills 'profiles' rather than just their levels. ${ }^{72}$

\footnotetext{
${ }^{69}$ See Juan A. Bogliaccini and Aldo Madariaga, 'State Capacity and Social Investment: Explaining Variation in Skills Creation Reforms in Latin America', in Julian Garritzman, Silja Haüsermann and Bruno Palier (eds.), The World Politics of Social Investment, vol. 1: Welfare States in the 21st Century (Oxford: Oxford University Press, forthcoming).

${ }^{70}$ We substantiate this in more detail below.

${ }^{71}$ See Bogliaccini and Madariaga, 'State Capacity and Social Investment'.

${ }^{72}$ See also Bogliaccini and Filgueira, 'Capitalismo en el Cono Sur'; Filgueira, Welfare and Democracy in Latin America; Martínez-Franzoni, 'Welfare Regimes in Latin America'.
} 
Table 2. Country Groups in Social Policy and Skills-Formation Incorporation Strategies

\begin{tabular}{|c|c|c|}
\hline Country groups & $\begin{array}{c}\text { Social policy } \\
\text { incorporation } \\
\text { (twentieth century) }\end{array}$ & $\begin{array}{c}\text { Skills formation } \\
\text { incorporation } \\
\text { (twenty-first century) }\end{array}$ \\
\hline \multirow[t]{2}{*}{ Advanced/Universalising } & \multirow{2}{*}{$\begin{array}{l}\text { Argentina } \\
\text { Chile } \\
\text { Costa Rica } \\
\text { Uruguay }\end{array}$} & Chile \\
\hline & & $\begin{array}{l}\text { Bolivia } \\
\text { Brazil } \\
\text { Colombia } \\
\text { Peru } \\
\text { Venezuela }\end{array}$ \\
\hline \multirow[t]{2}{*}{ Intermediate/Dual } & \multirow{2}{*}{$\begin{array}{l}\text { Brazil } \\
\text { Colombia } \\
\text { Mexico } \\
\text { Panama } \\
\text { Venezuela }\end{array}$} & $\begin{array}{l}\text { Argentina } \\
\text { Costa Rica } \\
\text { Uruguay }\end{array}$ \\
\hline & & $\begin{array}{l}\text { Ecuador } \\
\text { El Salvador } \\
\text { Mexico } \\
\text { Panama }\end{array}$ \\
\hline Laggard/Exclusionary & $\begin{array}{l}\text { Bolivia } \\
\text { Ecuador } \\
\text { El Salvador } \\
\text { Guatemala } \\
\text { Honduras } \\
\text { Nicaragua } \\
\text { Peru }\end{array}$ & $\begin{array}{l}\text { Guatemala } \\
\text { Honduras } \\
\text { Nicaragua }\end{array}$ \\
\hline
\end{tabular}

Source: Author's elaboration based on Filgueira, Welfare and Democracy in Latin America; Segura-Ubiergo, The Political Economy of the Welfare State.

Using the two cleavages explained above, we advance the characterisation of our four types using secondary sources in order to illustrate these profiles' main features as well as their historical trajectories. We use information from specific countries to illustrate each profile's dynamics.

\section{Universalising Skills Profile}

We call the skills profile characterised by a virtuous circle of skills supply in the last two decades 'universalising'. This label captures the successful efforts that the countries in this cluster have made, and continue to make, in terms of incorporating their populations through skills formation, evidenced by their approach towards advanced countries' levels of secondary education completion. The term captures, at the same time, the still-insufficient current levels achieved in other domains, such as tertiary education and improvement of educational quality. This group is composed of Brazil, Colombia, Venezuela and Chile, and we include Bolivia and Peru, given that they show similar indicators. ${ }^{73}$ Between 2000 and 2015, these countries decreased the percentage of the population with only primary schooling or less by about 12 points, on average, and have increased the completion of secondary education by around 25 points (see Table 3). These countries have also excelled in the

\footnotetext{
${ }^{73} \mathrm{We}$ analyse the case of Chile separately because of its particularities as an outlier.
} 
improvement of educational quality. At the secondary level, they show a preeminence of general schooling, while there is a relatively high development of VET at the tertiary level.

All countries in this group - including Chile - have benefited from the recent commodity boom, strengthening the demand for skilled labour from capital-intensive industries such as oil, mining and forestry. This has also produced unusually high revenues from commodity exports, which has facilitated a supply response in terms of new policies and institutions. Although in many respects Chile is an outlier, it shares with this cluster the important advance, in the last decades, of universalising the completion of secondary education and improving quality (although from very different starting levels), as well as driving an increase in educational expenditure through the commodity-boom dynamic.

The demand for skills from booming sectors, the extra state revenue they generated and an extraordinary capacity to form stable government coalitions during the period permitted the countries in this cluster to overcome their uneven institutional and policy legacies in terms of skills formation. Bolivia, Brazil and Chile share the characteristic of being highly innovative in the last two decades, but present very different profiles in terms of policies and emphases. Below, we devote a separate section to Chile.

Bolivia showed impressive educational advances between 2000 and 2014. Much of the country's education provision moved to VET, especially at the postsecondary level. The percentage of people aged 20-24 that completed secondary education increased by 32 points, reaching close to 80 per cent, among the highest in the region today (see Table 3). Expenditure on education increased to $6.3 \mathrm{per}$ cent of GDP, also among the highest in the region. Enrolment in VET at the secondary level remained relatively stable, while VET at the post-secondary level more than doubled from 7.1 per cent in 2000 to around 15 per cent in $2011 .^{74}$

After decades of failed reform efforts, in 2010 the Morales government managed to pass a comprehensive educational reform, with wide support. Known as the Avelino Siñani-Elizardo Pérez Law, it strengthened the link between education and the productive sector, in both its general and VET components, with an emphasis on communitarian economies and indigenous culture, in step with the government's overall orientation. ${ }^{75}$ The law also created new public institutions at the post-secondary VET level and technological universities to serve the needs of indigenous communities.

While secondary and tertiary education in Bolivia is mostly public, private provision is particularly salient in post-secondary VET ( 77 per cent of technical institutes and close to 50 per cent of universities). ${ }^{76}$ The main actor in the sector is the Instituto de Formación y Capacitación Laboral (Institute of Education and Vocational Training, INFOCAL), which was transferred in the 1980s from the state to the main employer association, Confederación de Empresarios Privados de Bolivia (Confederation of Bolivian Private Businesses, CEPB). In spite of this,

\footnotetext{
${ }^{74}$ Data from UNESCO's UIS database and Sevilla, 'Panorama de la educación técnica', p. 36.

${ }^{75}$ Ibid., pp. 26-7; Mario Yapu, 'Desafíos de la educación técnica y profesional y política educativa en Bolivia', Edetania, 48 (Dec. 2015), pp. 81-100.

${ }^{76}$ Kathlen Lizárraga, Educación técnica y producción en Bolivia (La Paz: PIEB, 2011), p. xv, p. 49.
} 
Table 3. Changes in Education Attainment and Cognitive Scores, 2000-15, by Country




Table 3. (Continued.)

\begin{tabular}{|c|c|c|c|c|c|c|c|c|c|}
\hline & \multicolumn{3}{|c|}{$\begin{array}{l}\text { Percentage of population aged } 15-64 \text { with } \\
0-5 \text { years of education }\end{array}$} & \multicolumn{3}{|c|}{$\begin{array}{l}\text { Percentage of population aged } 20-24 \text { that } \\
\text { completed secondary education }\end{array}$} & \multicolumn{3}{|c|}{ Cognitive scores } \\
\hline & Circa 2000 & Circa 2014 & Change & Circa 2000 & Circa 2014 & Change & 2006 & 2013 & Change \\
\hline Average change & & & -7.3 & & & 15.1 & & & 26.0 \\
\hline Guatemala & 53.9 & 52.4 & -1.5 & 21.2 & 33.0 & 11.8 & 451.4 & 491.4 & 40.0 \\
\hline Honduras & 45.3 & 34.7 & -10.6 & 20.4 & 42.7 & 22.3 & - & 488.3 & - \\
\hline Average change & & & -7.0 & & & 16.5 & & & 23.2 \\
\hline
\end{tabular}

Source: Authors' elaboration based on ECLAC's CEPALSTAT database; UNESCO, Comparación de resultados. 
research has shown evidence that weak coordinating capacities among private employers in the realm of skills formation have reduced the ability to set common standards, making the supply of courses grow disproportionately and without control over labour-market adequacy or quality, therefore reducing the recognition of skills acquired through VET.

Brazil has also shown an impressive advancement in the last few decades with regard to closing educational gaps. Between 2000 and 2014, the percentage of the population aged 20-24 that completed secondary education grew by more than 30 points, approaching the region's leaders (see Table 3). As this table shows, educational quality as measured in regional test scores also improved notably. This reflects an important expenditure effort between 2000 and 2012. ${ }^{78}$ Provision of VET is very low at the secondary level, covering only around 4 per cent of students in 2014 (up from 2 per cent in 2003), but has increased significantly in the postsecondary level, from around 4 per cent in 2003 to more than 13 per cent in 2012. ${ }^{79}$

While general education is also mostly state-run in Brazil, along the lines of the other countries in this cluster, VET counts a strong private component, with close to 50 per cent and 80 per cent of its provision supplied by the private sector at the secondary and post-secondary levels, respectively. ${ }^{80}$ The most prominent institutions involve those of the so-called 'S-system', a publicly financed (through payroll taxes) but privately administered VET system going back to the ISI years. ${ }^{81}$ The S-system covers secondary and post-secondary formal education as well as training courses.

Brazilian employers have been actively working across all programmes, and the employer administration of the S-system has increased its power and coordinating capacity in VET and education in general, maintaining its overall high quality and recognition. In fact, the S-system is responsible for the provision of around 43 per cent of all VET in the country. ${ }^{82}$ Moreover, in parallel to strengthening state provision, public efforts at incorporating poorer populations into the VET systems through demand-side transfers and scholarships have sought to integrate these public efforts with the S-system institutions.

\section{Chile: The Universalising Outlier}

Chile appears to be an outlier in the region, as it has advanced greatly in coverage and quality, even starting from relatively very high levels. Between 2000 and 2015,

\footnotetext{
${ }^{77}$ Ibid., p.xv; Kathlen Lizárraga, 'Formación para el trabajo en Bolivia: La paradoja de un país extractivo', Development Research Working Paper Series, no. 03/2015 (La Paz: INESAD, 2015), p. 10.

${ }^{78}$ OECD, Education Policy Outlook: Brazil (Paris: OECD, 2015), p. 15.

${ }^{79}$ Data from UNESCO's UIS database.

${ }^{80}$ Sevilla, 'Panorama de la educación técnica', p. 72.

${ }^{81}$ S-system institutions operate at the sectoral level. The more important ones are the Serviço Nacional de Aprendizagem Industrial (National Service for Industrial Training, SENAI) - Serviço Social da Indústria (Industry Social Service, SESI), and the Serviço Nacional de Aprendizagem Comercial (National Service for Commercial Training, SENAC) - Serviço Social do Comércio (Commerce Social Service, SESC), both founded in the 1940s. Several other institutions have been established since the 1990s.

${ }^{82}$ André Portela Souza, Lycia Lima, Amanda Arabage, Juliana Camargo, Thiago de Lucena and Sammara Soares, 'Vocational Education and Training in Brazil', IADB Discussion Paper, no. IDB-DP-387 (Washington, DC: Inter-American Development Bank, 2015).
} 
Chile increased the number of people aged 20-24 with completed secondary education, reaching close to 85 per cent (see Table 3). This expansion occurred due to the growth of the private system, which comprises over 50 per cent of enrolment in secondary and tertiary education. In the case of post-secondary VET, private provision is virtually full. ${ }^{83}$ Educational expansion in post-secondary VET has been especially significant, increasing from around 30 per cent of the higher education system in 2000 to over 50 per cent, thanks to state-subsidised loan and scholarship programmes.

Three aspects separate Chile from the rest of the countries in this cluster. First, Chile has managed to universalise not only secondary education, but also the tertiary educational level. Second, the strong VET orientation has translated into a higher percentage of VET programmes both at the tertiary level - like the other countries in this cluster - as well as at the secondary level. Finally, the quality of Chilean educational programmes, as measured through cognitive scores, has continued to improve and is currently the best in the region. In other words, Chile has been able to universalise education at all levels, put a strong emphasis on VET at all levels, and maintain a relatively - for the region - high quality. However, Chile's problems remain the high segmentation of its educational system between good and bad schools and between private and public providers, and its varied successes. ${ }^{84}$ The situation with the growing VET component is telling.

In Chile's VET segment, the private sector as a whole does not have a unified structure to coordinate efforts; this is one of the main shortcomings of the country's skillsformation system. ${ }^{85}$ In fact, while business chambers administer a handful of relatively high-quality secondary and post-secondary institutions, a majority of private providers are for-profit institutions with varying degrees of both coordination with the private sector and educational quality. In this context, different efforts by governments to promote policies including bi-partite or tri-partite coordination instances - such as the defunct Chile Califica and the current Chile Valora - have either failed to engage the private sector in broad coordination efforts or, importantly, narrowed the scope of topics to define, such as certification criteria, study profiles and trajectories.

Overall, the universalising profile combines a rapid increase in attainment rates with a clear focus on VET development, albeit using highly diversified strategies. VET schemes are highly valued by employers in countries with higher business coordination like Brazil, and less so in countries with lower coordination like Bolivia and Chile. Moreover, rapid coverage expansion poses challenges in terms of the segmentation between private and public providers, VET and general education, and within the VET system, between secondary and post-secondary. Chile's trajectory is telling: while the country has significantly improved coverage on all levels and even reduced quality differentials among educational segments, these remain among the highest when comparing with the OECD, and when measured with Programme for International Student Assessment (PISA) scores, overall

\footnotetext{
${ }^{83}$ Sevilla, 'Panorama de la educación técnica', p. 36.

${ }^{84}$ Busso et al., Disconnected. On segmentation and quality differentials, see Mizala and Torche, 'Bringing the Schools Back In'.

${ }^{85}$ Interview by the authors with the director of the Human Capital Agenda at the Peak Employers' Association (CPC), a former official at the Ministry of Education, and the director of the Department of Secondary Education, Ministry of Education, April/May 2017, Santiago.
} 
educational quality shows no significant advance in the last decade. ${ }^{86}$ The large private sector in Chile has been both a way to get around political stalemate over educational policy - contributing to advances in coverage and attainment - and a problem when it comes to regulating the quality and equality of educational services, as evidenced in the continued segmentation of the skills-formation system.

\section{Exclusionary Skills Profile}

In the antipodes of the universalising profile, we find the exclusionary profile. The exclusionary skills profile includes Honduras and Nicaragua, and we have also included Guatemala, given this country's coincidences of indicators with countries in this cluster (see Table 1). The name 'exclusionary' conveys the idea that these countries have not had successful processes of social incorporation during the twentieth and twenty-first centuries, in terms of both the general development of welfare institutions and the particular case of skills formation. ${ }^{87}$

The exclusionary profile shows the lowest average levels of education enrolment, attainment and cognitive scores in the region, as well as the smallest gains in these indicators in the past 15 years. Interestingly, two countries in this cluster, Honduras and Guatemala, combine this with a high provision of VET at the secondary level. The magnitude of enrolment in secondary VET as opposed to academic programmes in these countries reflects the segmented nature of the slow incorporation process into secondary education. While traditional programmes remain populated with the upper sectors of society, VET-oriented programmes are used as a substitute to get around the problem of low enrolment, low completion and high dropout rates, and not as a source of specific skills formation.

The case of Guatemala, a country that with all probability belongs to this cluster, is a good illustration of these dynamics. Since at least the 1970s, the country has tried to implement a VET type of educational alternative, in order to provide a vocational exit even to populations with only primary schooling, which runs contrary to common practice in the world and the region, where VET alternatives are present mostly at the upper-secondary level. This educational alternative was provided by the Experimental Basic Education Institutes with Vocational Orientation (PEMEMs) founded in 1973 and existing today, but which have lost significance over time as the country has turned its efforts - almost exclusively - towards increasing primary education coverage.

The penetration and policy role of international financial assistance in these countries is the most significant in the region. Almost every new educational programme, in particular those oriented towards enhancing VET to populations not covered by the existing educational institutions, is financed and designed from abroad and, therefore, has finite operational horizons and relatively narrow objectives in terms of skills formation. ${ }^{88}$

\footnotetext{
${ }^{86}$ Despite increases in PISA scores (mathematics and reading) from 2006 to 2016, differences are not statistically significant.

${ }^{87}$ See Filgueira, Welfare and Democracy in Latin America.

${ }^{88}$ Interview by the authors with German Gesellschaft für Internationale Zusammenarbeit (Organisation for International Cooperation, GIZ) and United States Agency for International Development (USAID) employees, Guatemala City, June 2018.
} 
Skills formation for the workforce in the three countries is instituted primarily through VTIs formally dependent on labour ministries. Although utilising different strategies, these VTIs are run primarily by employers, while funded mostly by employers and international donors. The Guatemalan Instituto Técnico de Capacitación y Productividad (Technical Institute for Training and Production, INTECAP) stands out in the region because of its quality and employers' diploma recognition. This recognition goes hand in hand with employers' strong involvement in the institute and the government's weak capacity for policy orientation. The institute has, therefore, a high orientation towards the relatively narrow skills demands from employers specialised in labour-intensive sectors such as agriculture, low-productivity services like tourism and call centres, or capital-intensive agricultural manufactures like palm oil and sugar. Moreover, although INTECAP offers upper-secondary school diplomas, they represent a tiny fraction of the overall enrolment in this level. ${ }^{89}$

Our last two profiles pertain to a common root that we call 'dual'. Duality reflects the existence of 'the stratified aspects that characterized mature systems without presenting the universalized coverage of the stratified universalism regimes' ${ }^{90}$ In other words, these profiles leave important parts of the population without access to even a basic level of general skills through secondary education, and radically segmented (in fact, dual) life and work dynamics are generated among the population due to the differences between those who stay in education and those who do not.

\section{Dual Academic-Oriented Profile}

'Dual academic-oriented', as we call it, encapsulates a skills profile that combines strong institutional legacies and state capacities with a lack of meaningful advance in covering education gaps over the last two decades. Although governments in this cluster's countries have accompanied the regional upward trend in education investment as a share of GDP, they have not undertaken major reforms to increase skills supply. Therefore, while showing relatively high coverage and quality indicators overall, these countries have stagnated to the extent that they have reinforced their dualism instead of advancing in the universalisation of their skills-formation systems. Uruguay and Argentina, for example, are among the countries that have advanced less in closing educational gaps in the last two decades, despite also being among those countries that have achieved the highest levels of institutional strength and state capacity in Latin America, as well as earlier universalisation of primary schooling. While Costa Rica has improved its secondary completion, the country lags well behind the more successful universalising countries in terms of secondary education completion and coverage. Moreover, Costa Rica and Uruguay are the only countries with an overall reduction in cognitive scores in the region over the last few decades, while Argentina is among those with the lowest gains (see Table 3).

In this context, relatively high - for the region - enrolment in tertiary education reflects efforts to overhaul secondary systems for the high achievers to reach

\footnotetext{
${ }^{89}$ Interview by the authors with INTECAP acting director, Guatemala City, June 2018.

${ }^{90}$ Filgueira, Welfare and Democracy in Latin America, p. 24.
} 
university, but without offering alternatives to those left behind. In fact, these countries are characterised by relatively low levels of VET compared to the rest of the region, particularly at the post-secondary level. Moreover, in contrast with cases like Brazil and Colombia, or even Guatemala, VET schemes in this profile are not particularly valued by employers. In other words, while very successful in the first incorporation phase during ISI, these countries have not been able to further advance in skills formation in the second incorporation process.

The case of Uruguay illustrates well the dynamics of this group. Despite being an earlier developer of the welfare state and public education in the region, the advancement of education over the last few decades has been disappointing and it is not far-fetched to suggest that the country has stagnated on this matter. ${ }^{91}$ In fact, between 2000 and 2014 the country increased its share of population aged 20-24 that completed secondary education by only 7 per cent, lagging behind the rest of the region together with some of the Central American laggards (see Table 3). With respect to VET, despite recent efforts, enrolment at the secondary level increased only by about 1 per cent from 2000 to $2013 .^{92}$

Given that the country has strong institutions and above-average state capacity for the region, part of the explanation for this stagnation lies in societal actors' inability to form coalitions that push the necessary reforms. ${ }^{93}$ On the one hand, strong teachers' unions have stalled educational reform in the country under both centre-right and leftist governments. ${ }^{94}$ On the other hand, leading export sectors - mostly cattle exportation and agro-industrial production of soybeans or rice are capital-intensive, posing little pressure on governments to expand the skilled workforce. In fact, with the rapid incorporation of technology in the last two decades, these sectors have demanded less but better-skilled labour. ${ }^{95}$

Overall, the dual academic-oriented profile has lagged behind the universalising group in terms of incorporation through skills formation. The legacy of incorporation - including strong unions - has increased the costs of educational reform, while low skills demand - and an uncoordinated employer sector - has reduced reform pressures.

\section{Dual VET-Oriented Profile}

The profile we name 'dual VET-oriented' combines a moderate and uneven advance in coverage, albeit with a prevalence of VET at both secondary and postsecondary levels. This group is the most heterogeneous of the four and resembles what are labelled 'hybrid' or 'mixed regimes' in the comparative capitalisms literature. ${ }^{96}$ It includes countries as diverse as El Salvador, Mexico, Ecuador and Panama. Here, inclusion into social protection and, in particular, education has been a late if

\footnotetext{
${ }^{91}$ Juan A. Bogliaccini and Federico Rodríguez, 'Education System Institutions and Educational Inequalities in Uruguay', CEPAL Review, 116 (Aug. 2015), pp. 85-99.

${ }^{92}$ Data from UNESCO's UIS database.

${ }^{93}$ See Bogliaccini and Madariaga, 'State Capacity and Social Investment'.

${ }^{94}$ Pribble, Welfare and Party Politics.

${ }^{95}$ See Ignacio Apella and Gonzalo Zunino, Technological Change and the Labor Market in Argentina and Uruguay: A Task Content Analysis (Washington, DC: World Bank, 2017).

${ }^{96}$ See Schneider and Paunescu, 'Changing Varieties of Capitalism'.
} 
still uneven achievement of the second incorporation period. Improvement seems confined to extending primary education, but with disappointing gains, particularly in terms of secondary education. Ecuador appears to be the country closest to entering the universalising group. In fact, Ecuador has significantly improved its indicators in all levels, has heavily invested in both academic and VET tertiary education, and has substantially improved cognitive scores, while still falling behind the universalising group's great catch-up (see Table 3). ${ }^{97}$ In the case of Panama, although it had a higher development of social policy during the twentieth century, its lower educational indicators cluster the country with Mexico and Ecuador rather than Costa Rica, Argentina and Uruguay. Finally, El Salvador seems to be exiting the group of exclusionary profiles and entering the dual VET-oriented category, with important improvements in primary education but less impressive ones in secondary education and quality.

A more interesting case in this group is Mexico, which has made some improvements over time, yet not enough to put the country on a course towards reaching the universalising group, as seems to be the case with Ecuador. In spite of some advancement, particularly in reducing the population with less than five years of education, 50 per cent of the country's population aged 20-24 still does not complete secondary education (Table 3). Moreover, the flow of skills doesn't seem to be geared towards increasing the stock of skills, with enrolment in both secondary and tertiary education among the lowest in the region, only ahead of countries in the exclusionary group (Table 1). This, coupled with stark regional disparities and large labour-market informality, makes the prospect of incorporation through skills formation a difficult one.

Although Mexico was among the most advanced countries in the region in terms of industrialisation, the country was not able to form a strong and coordinated skills-formation system, as Brazil did. ${ }^{98}$ Unlike in Brazil, where the S-system became a central focus for the expansion of skills formation, during the second half of the twentieth century Mexico saw the emergence of a myriad of state institutions catering to the necessities of specific sectors and firms, without coordination and with an increasing overlap of functions over time. A brief historical recount, and the number of institutions and names that arise, serves to make the point. In the mid-1960s, Mexico founded training institutions for employed workers under the umbrella of the Ministry of Education: Centros de Capacitación para el Trabajo Industrial (Training Centres for Industrial Work, CECATIs) and Institutos de Capacitación para los Trabajadores (Workers' Training Institutes, ICATs). During the 1970s, other institutions where founded to cover secondary VET: the Dirección General de Educación Tecnológica Agropecuaria (Directorate-General for Agricultural Technology Education, DGETA), the Dirección General de Educación Tecnológica Industrial (Directorate-General for Industrial Technology Education, DGETI), and the Dirección General de

\footnotetext{
${ }^{97}$ See Ben Ross Schneider, Pablo Cevallos Estarellas and Barbara Bruns, 'The Politics of Transforming Education in Ecuador: Confrontation and Continuity, 2006-17', RISE Working Paper, no. 18/021 (RISE, 2018).

${ }^{98}$ See Ívico Ahumada Lobo, 'Formación profesional y capacitación en México', Serie Macroeconomía del Desarrollo, no. 153 (Mexico City: CEPAL, 2014), pp. 54-5.
} 
Educación en Ciencia y Tecnología del Mar (Directorate-General for Marine Science and Technology Education, DGECyTM). These were catalogued as specialised bachilleratos tecnológicos (technological baccalaureates), allowing access to tertiary education. Meanwhile a different institution, the Colegio Nacional de Educación Profesional Técnica (National College of Professional Technical Education, CONALEP), was founded to provide dual-education and direct labourmarket access. Finally, the old Instituto Politécnico Nacional (National Polytechnic Institute, IPN) was supposed to concentrate on post-secondary studies. As the country entered the Washington Consensus, the old ISI institutions adapted by reducing their specialisation and increasing the overlap of their functions, therefore reinforcing their lack of coordination, which, according to some experts, is the main drawback of the system. ${ }^{99}$ For example, CONALEP courses no longer give direct labour-market access alone but can now lead to higher education, while the bachilleratos tecnológicos provide, today, an undifferentiated supply of courses, mostly in the realm of administrative sciences. ${ }^{100}$

The proliferation of institutions and programmes also obscures an inability to effectively tackle existing problems and gaps in terms of skills formation. One example is the active labour-market programmes linked to the public and private supply of VET. In the context of the debt crisis, Mexico established the Programa de Becas de Capacitación para Trabajadores (Workers' Training Scholarship Programme, PROBECAT) to provide a monetary transfer and shortterm training to the unemployed. The programme was made permanent in 1988, establishing a training scholarship for the (mostly young) unemployed that could be redeemed in a number of ways in school-based (public and private) and in-firm training, but without awarding a certificate for the acquired competencies. This problem remained over time after each iteration of the programme - which changed names to Sistema de Capacitación para el Trabajo (Work Training System, SICAT) in 2002 and again to Becas de Capacitación para el Trabajo (Work Training Scholarships, BÉCATE) in 2005, while maintaining its basic structure and benefits - and became a key explanation for the programme's shortcomings in terms of effective skills formation and labour-market incorporation. ${ }^{101}$ This occurred in spite of the programme being one of the 'most evaluated programmes in Latin America'. ${ }^{102}$ Today, President Andrés Manuel López Obrador's new flagship scholarships programme, called Jóvenes Construyendo el Futuro (Young People Building the Future), follows in the same footsteps, providing funding for in-firm training with few obligations as to the type and content of training and the possible certification of the acquired competencies.

This situation also reflected pervasive regional disparities in terms of economic development and the resilience of the informal segment of the labour market. After entering the North American Free Trade Agreement (NAFTA), the dynamic

\footnotetext{
${ }^{99}$ OECD, Mexico: Policy Priorities to Upgrade the Skills and Knowledge of Mexicans for Greater Productivity and Innovation (Paris: OECD, 2015).

${ }^{100}$ Ahumada Lobo, 'Formación profesional'.

${ }^{101}$ Ibid., p. 30.

${ }^{102}$ Ívico Ahumada Lobo, 'Requerimientos para una efectiva política de capacitación de los trabajadores', in José Luis Calva (coord.), Educación, ciencia, tecnología y competitividad (Mexico City: UNAM / Miguel Ángel Porrúa, 2007), p. 296.
} 
northern regions were revitalised by the arrival of multinational companies (MNCs) that strengthened productive and trade links with the United States. Inversely, the more backward southern regions have maintained productive structures closer to their southern Central American neighbours. However, fierce competition from China, and the displacement of US demand for more skilled production to this country, has reduced the demand for higher-skilled workers, even in the more dynamic industries. ${ }^{103}$ As a consequence, employment in the manufacturing industry has shrunk and this sector has provided only meagre impulse to sustain employment and economic growth, resulting in a decreasing demand for skilled workers and many students with VET qualifications ending up in the informal sector. ${ }^{104}$

In sum, the dual VET-oriented profile is the most heterogeneous of the four. The stock of skills is moderate, evidencing only partial success of incorporation efforts in different periods. As the Mexican case exemplifies, this is due to, among other things, lack of coordination and a proliferation of institutions and programmes that do not tackle existing problems and gaps effectively. At the same time, the flows of skills reflect a sluggish skills demand and overall inability to upgrade old institutions to new purposes.

\section{Conclusions}

Following the comparative capitalisms literature, in this article we have attempted to provide a novel characterisation of the intra-regional variation in skills-formation systems in Latin America as a necessary stage towards understanding the politics behind that variation. We claim that, while sharing certain underlying characteristics, skillsformation systems are distinct from welfare regimes and should be analysed as potentially complementary but separate structures, offering particular characteristics for social incorporation strategies and for economic and social development.

Our analysis challenges the dominant idea that the region is characterised by an overall pattern of skills supply, as depicted in the HME model. While showing that the region shares common patterns, underlying differences in skills supply generate distinctive configurations. Overall, investment in skills remains scarce as economic structures dominated by low-productivity sectors demand mostly general and lowlevel skills, relative to advanced economies. However, while this is true for the region overall, we have highlighted meaningful intra-regional differences, evidenced by the stock of skills as well as its current flows in terms of quantity, quality and type. Based on these indicators, we argue for the existence of four skills supply profiles in the region: universalising, dual academic-oriented, dual VET-oriented and exclusionary.

The universalising group provides overall high stocks of general skills, high flows in secondary education, increasing quality and a preference for VET alternatives, particularly at the post-secondary level. Apart from Chile, and despite improvements, countries in this group still lag behind in terms of the universalisation of

\footnotetext{
${ }^{103}$ John Sargent and Linda Matthews, 'Capital Intensity, Technology Intensity, and Skill Development in Post China/WTO Maquiladoras', World Development, 36: 4 (2008), pp. 541-59.

${ }^{104}$ Ahumada Lobo, 'Formación profesional', pp. 54-5.
} 
tertiary education. The commodity-boom period provided a crucial context for these countries to increase their provision and level of skills, and countries hitherto considered laggards have jumped on the bandwagon of social incorporation thanks to their successful skills-formation strategies. A combination of private and state provision and an increasing role for VET alternatives seems to be behind these success stories. Despite starting from a comparatively more advanced situation, Chile has continued to improve in all its indicators. The fact that the country still shows significant quality differentials among educational systems and levels, and has not been able to catch up with advanced countries, suggests that there is still a large margin for governments to improve in their skills-formation incorporation strategies. The comparison between the successful case of Brazil and those of Bolivia and Chile shows the importance of employer coordination in the context of skillsformation systems with a large component of private provision.

Conversely, other formerly more advanced countries in the region, like Argentina, Costa Rica and Uruguay, have been unable to further advance in closing skills-formation gaps. Therefore, at a relatively high level of stocks for the region, they have remained behind in terms of quantity flows, seen their quality reduced and relied mostly on academic-oriented programmes. This has consolidated dual systems where opportunities are highly segmented and educational pathways try to steer the best students towards accessing tertiary education without offering meaningful alternatives to those left behind. Conversely, countries in the dual VET-oriented group share with the latter the duality of their skills-formation trajectories, though at a comparatively lower level due to lower accumulated stocks of skills. They have advanced unevenly in the last decades, mostly reducing gaps in primary education, but have been far from successful in terms of universalising secondary education and improving quality. Unlike the other dual-profile group members, they offer a high presence of VET alternatives in both secondary and post-secondary levels. Finally, the exclusionary profile shows disappointing results in terms of stocks and flows of skills. As we have shown through the case of Guatemala, in these countries - also characterised by large agricultural and lowproductivity sectors - the scant demand for skills is satisfied through business solutions, with little state presence. Unlike in the dual groups, in this case a relatively successful educational pathway is only available to a small minority. In a context of very low state capacities, employers have solved their minimal requirements for skilled labour by managing highly coordinated VTIs while leaving the immense majority lacking the most basic skills, even in terms of completion of primary education.

Overall, the proposed skills profiles are meaningful for understanding the opportunities and challenges of development-oriented policies and strategies in a region in which both production and political regimes have changed dramatically since the end of inward-oriented growth models. The picture we paint suggests that in many cases there seems to be an inconsistency between overall human and economic development levels and investment in skills formation. In the aftermath of the liberalisation period, old regional leaders, such as Argentina, Costa Rica and Uruguay, have lost steam against rapid improvers such as Bolivia, Colombia and Brazil. These differences are meaningful precisely because they signal diverse political and economic trajectories and, arguably, their future evolution. In other words, they 
present interesting grounds for a more fine-grained investigation of the politics behind different skills supply profiles.

Finally, while skills-formation profiles are expected to remain closely linked to demands from the productive sectors, these demands should not be understood as only coming from big domestic firms, as was usually the case during industrial capitalism. The labour-market globalisation trend will increasingly provide atomised demands for a growing number of global hotspots, augmenting regional disparities and further incentivising brain-drain dynamics. At the same time, the development of robotisation and artificial intelligence will make a sizeable group of low-skilled jobs redundant, further increasing the skill premiums and the inequality gap. In this context, universalising the acquisition of quality technical skills by middle- and lower-class teenagers represents by itself an enormous opportunity for social and economic development in Latin America. Equally important, such a strategy of skills formation accompanying productive transformation is consistent with a strategy of social incorporation of excluded social groups and minorities, as the barriers to access and attainment of quality education and the acquisition of skills that are valued in the labour market continue to be the elephant in the room in Latin American education reform efforts.

Acknowledgements. The authors would like to thank Mauricio Farías, Nicolás Grau, Fernando Filgueira, Rafael Piñeiro, Diego Sánchez-Ancochea, María Paola Sevilla, Ben Ross Schneider and the four anonymous reviewers at JLAS for their valuable advice regarding our argument, data and previous versions of the article. We are also indebted to the participants in the LSE-COES 2016 Inequalities Conference (Santiago de Chile) and the REPAL 2017 Annual Conference (Lima, Peru). Cecilia Giambruno provided valuable research assistance. Aldo Madariaga acknowledges support from the Centro de Estudios de Conflicto y Cohesión Social (Centre for Social Conflict and Cohesion Studies, COES) (Grant CONICYT/FONDAP/ 15130009), the Fondo Nacional de Desarrollo Científico y Tecnológico (National Fund for Scientific and Technological Development, FONDECYT) de Iniciación (N. 1190487) and the Comisión Nacional de Investigación Científica y Tecnológica (National Commission for Scientific and Technological Research, CONICYT) (Grant CONICYT/PCI/REDES190097). Juan A. Bogliaccini acknowledges support from the Universidad Católica del Uruguay (Grant APOYO-INVESTIGADORES/2017) and the Fondo Clemente Estable (FCE_1_2017_1_135444) awarded by the Uruguayan Agencia Nacional de Investigación e Innovación (Agency for Research and Innovation, ANII).

\section{Spanish abstract}

Las investigaciones sobre las políticas de formación de habilidades en Latinoamérica se encuentran muy poco desarrolladas. Este artículo ofrece una caracterización novedosa de la oferta de habilidades en la región o 'perfiles de oferta de habilidades', inspirándose en la literatura comparativa sobre los capitalismos. Identificamos cuatro configuraciones de perfiles de oferta de habilidades - universalizadores, dual orientado a lo académico, dual orientado a la educación vocacional y capacitación (VET por sus siglas en inglés) y excluyente - y analizamos sus dinámicas históricas. Así, desafiamos las evaluaciones generales de los sistemas de formación de habilidades en América Latina como pertenecientes a un solo tipo. Esto prepara el terreno para un entendimiento más profundo de las políticas de habilidades en la región y su conexión con alternativas diferentes de desarrollo.

Spanish keywords: habilidades; América Latina; desarrollo; educación vocacional y capacitación 


\section{Portuguese abstract}

Pesquisas sobre as políticas de formação profissional são pouco desenvolvidas na América Latina. Inspirado pela literatura sobre capitalismos comparados, este artigo oferece uma caracterização inovadora da oferta de competências na região, ou um 'perfil de ofertas de competência'. Identificamos quatro configurações dos perfis de oferta de competência - universalizante, acadêmico dual, vocacional dual, e excludente - e analisamos suas dinâmicas históricas. Ao fazê-lo, desafiamos a visão comum de que o sistema de formação de competências na América Latina pertence a um tipo comum e dominante. Essa abordagem permite um entendimento das políticas de competência na região e suas conexões com diferentes alternativas de desenvolvimento.

Portuguese keywords: competências; América Latina; desenvolvimento; educação e treino vocacional

Cite this article: Bogliaccini JA, Madariaga A (2020). Varieties of Skills Profiles in Latin America: A Reassessment of the Hierarchical Model of Capitalism. Journal of Latin American Studies 52, 601-631. https://doi.org/10.1017/S0022216X20000322 